FITRAH Jurnal Kajian Ilmu-ilmu Keislaman

Vol. 04 No. 1 Juni 2018

e-ISSN : 2460-2345, p-ISSN: 2442-6997

Web: jurnal.iain-padangsidimpuan.ac.id/index.php/F

\title{
POLA PEMAHAMAN KEAGAMAAN MASYARAKAT SIMPANG EMPAT PASAMAN BARAT \\ (Studi Terhadap Aliran Haqqul Yaqin Tarekat Naqsabandiyah)
}

\author{
SAWALUDDIN SIREGAR \\ IAIN Padangsidimpuan \\ sawaluddinsiregar@iain-padangsidimpuan.ac.id
}

\begin{abstract}
Abstrak
Haqqul Yaqin Tarekat Naqsabandiyah is one of the tarekat that developed in Simpang Empat Pasaman Barat, in spreading sufistism, it uses remembering Methode (dzikir)as a form of ritual and its teaching. The purpose of ritual activities is to get grace, mercy, pleasure and get the assistance in the world and hereafter, also get the special excess ( such as, magic and treatment), then also hopefulness to achieve closeness with Allah as the ultimate goal. If it is considered, Haqqul Yaqin Tarekat naqsabandiyah has similarity with tarekat muktabarah, it can see based on the theory, basic teaching and also doing the syariat based on Al-Qur'an and Sunnah also Qaul Ulama. However, in some case haqqul Yaqin Tarekat Naqsabandiyah is different with Muktabarah tarekat, such as, it's about the acceptance of new students, wirid, training, tawajjuh and tends to spritual welfare and individual's supernatural power.
\end{abstract}

Keywords: Tasawuf, Tarekat muktabarah, Naqsabandiyah, Sufistic

\begin{abstract}
Abstrak
Haqqul Yaqin Tarekat Naqsabandiyah adalah salah satu tarekat yang berkembang di Simpang Empat Pasaman Barat, dalam menyebarkan ajaran sufistik dengan menggunakan metode zikir sebagai bentuk ritual dan ajarannya.Tujuan dari aktivitas ritual yang dilaksanakan adalah untuk mendapatkan rahmat, nikmat, ridha, mendapat pertolongan di dunia dan akhirat, mendapat kelebihan-kelebihan (kesaktian dan pengobatan) serta berupa harapan dari upaya untuk mencapai kedekatan dengan Allah sebagai tujuan akhir. Bila diperhatikan Haqqul Yaqin Tarekat Naqsabandiyah nampak mempunyai kemiripan dengan tarekat muktabarah mengenai ajaran dan amalan dasar serta menjalankan syariat berlandaskan al-Qur'an dan Sunnah serta qaul ulama. Namun dalam bebrapa hal Haqqul Yaqin Tarekat Naqsabandiyah berbeda dengan tarekat muktabarah, misalnya penerimaan pengikut baru, wirid, latihan, tawajjuh, dan cenderung pada kesejahteraan ruhani atau kekuatan ghaib individu.

Kata Kunci: Tasawuf, Tarekat muktabarah, Naqsabandiyah, Sufistik
\end{abstract}


FITRAH Jurnal Kajian Ilmu-ilmu Keislaman

Vol. 04 No. 1 Juni 2018

\section{PENDAHULUAN}

Ulama dan ahli keislaman membagi ajaran Islam pada dua komponen penting, esoterik dan eksoterik. Istilah esotorik berasal dari kata soteros yang berarti bagian dalam atau batin, antonim dari kata eksoteris yang berarti bagian luar. Kedua kata ini kemudian berkembang menjadi suatu istilah keagamaan yang menggambarkan dimensi batiniah dan lahiriah dalam ajaran agama. Eksoterik disinonimkan dengan syariah. ${ }^{1}$ Sebagai model keberagamaan yang lebih mementingkan aspek lahiriyah, sedangkan esoterik disinonimkan dengan tasawuf sebagai model keberagamaan yang lebih mementingkan aspek batiniah. ${ }^{2}$

Sebahagian ulama beranggapan bahwa pengalaman ajaran Islam yang bertumpu pada syariah yang dijabarkan melalui kajian fiqh oleh ulama fuqaha merupakan suatu kemestian yang mesti diikuti. Implikasinya dimensi esoterik terkesan dilupakan atau diabaikan. Sebaliknya ulama tasawuf dimensi esoterik merupakan esensi dan substansi ajaran agama yang bersifat intrinsik, transenden, dan universal. Berbeda dengan dimensi eksoteris yang merupakan tampilan lahiriyah yang berupa ajaran-ajaran formal dan sekaligus memberikan identitas secara spesifik terhadap agama. ${ }^{3}$ Komunitas muslim yang lebih mementingkan dimensi esoterik ini sering diidentikkan dengan komunitas sufi.

Praktek keagamaan Islam di Indonesia pada mulanya indentik dengan tasawuf dan fiqh. Inti kegiatannya adalah mengadakan renungan kebatinan untuk mencari jalan (tariqah) demi mencapai pengalaman kasyf, yang dengan hal itu para sufi bisa langsung bertemu dengan Allah. ${ }^{4}$ Kenyataan tersebut dapat

${ }^{1}$ Syariah berarti jalan. Sering juga disinonimkan dengan sabil, sirat, minhaj, tariqah, dan lain-lain. Ahmad Hasan mengungkapkan, al-Qur'an menggunakan dua kata yaitu ; syariah dan shir'ah dengan arti ad-din (agama) dalam pengertian jalan yang telah ditetapkan Allah bagi manusia atau dalam arti jalan yang jelas ditunjukkan oleh Allah untuk manusia. Hal ini didasarkan pada al-Qur'an misalnya pada surah al-Jatsiyah ayat 18 dan surah al-Maidah ayat 18 . Syariah dapat diartikan masalah-masalah pokok dalam islam. Dalam satu riwayat diinformasikan bahwa Nabi SAW pernah ditanya tentang syariah Islam, beliau menjawab bahwa yang dimaksudkan adalah shalat, zakat, puasa dan haji. Abu Hanifah dalam al-Alim wa al-Muta'allimin mengartikan syariah dengan kewajiban-kewajiban yang harus dijalankan dalam agama. Lihat Ahmad Hasan, Pintu Ijtihat Belum Tertutup, Bandung; Pustaka, 1984, hal. 7-8. Lihat juga Nurcholish Majid, Islam; Doktrin dan Peradaban, Jakarta; Paramadina, 1987, hal. 255

2 Ironisnya perbedaan pandangan ini sering berujung pertikaian antara kedua model keberagamaan tersebut. Sejarah mencatat sejak abad ke-3 sering terjadi ketegangan antara kedua belah pihak. Lihat Abdul Aziz Dahlan, Tasawuf Sunni dan Tasawuf Falsafi; Tinjauan Filosofis, dalam Jurnal Ulumul Qur'an No. 8 Vol. II/1999, hal. 26

${ }^{3}$ Yunasril Ali, Esoterisme; Perekat Pluralisme Bangsa, Jakarta, 2005, hal. 7

${ }^{4}$ Simuh, Islam dan Pergumulan Budaya Jawa, Bandung; Teraju, 2003, hal. 135 
dilihat dari corak ritual yang dijalankan oleh masyarakat Indonesia yang pada umumnya lebih mengutamakan ibadah mahdah yang normative.

"Ritual " yang bercorak tasawuf sampai sekarang terdapat dalam berbagai kalangan, baik masyarakat perkotaan maupun masyarakat pedesaan. Ritual yang dijalankan oleh masyarakat perkotaan dengan membentuk sebuah kelompok pengajian atau majlis taklim dengan menghadirkan seseorang pembimbing. Sedangkan diwilayah pedesaan lebih kepada pengajian yang dibina oleh seorang ulama yang berada diwilayah tertentu dengan menyampaikan dan menjelaskan kitab-kitab tertentu.

Oman Fathurrahman melihat setidaknya ada empat cara pandang mengapa sufisme semakin berkembang di kota-kota besar Indonesia, pertama; sufisme diminati oleh masyarakat perkotaan karena menjadi sarana pencarian makna hidup, kedua; sufisme menjadi pergulatan dan pencerahan intelektual, ketiga; sebagai sarana terapi psikologis, dan keempat; sufisme sebagai sarana untuk mengikuti trend dan perkembangan wacana keagamaan. ${ }^{5}$

Tiap tarekat mempunyai kumpulan dan organisasi dari para pengikutnya yang bercabang menjadi beberapa aliran sesuai dengan pemimpin yang diikuti sekaligus pemikiran yang dipegang. ${ }^{6}$ Di Sumatera misalnya, setidaknya ada empat sufi terkemuka, seorangnya dari mereka adalah Hamzah Fansuri (abad 17 M) di Barus, kota kecil dipantai barat Sumatera. Dia adalah sufi terkenal dengan karya taswufnya "Asror al-a'rifin dan syaraf al-asyikin serta kumpulan puisi sufistiknya. Dari keseluruhan karya tulisnya diketahui bahwa ia adalah penganut dan pengembang doktrin wahdat al-wujud karya Ibn Arabi. ${ }^{7}$

Sejak berdirinya kerajaan Islam di Pasai, kawasan itu menjadi titik sentral penyiaran agama Islam ke berbagai daerah di Sumatera dan pesisir utara pulau Jawa. Islam tersebar di Ranah Minangkabau atas upaya Syekh Burhanuddin Ulakan. Murid Abd Rauf Singkel yang terkenal dengan syekh Tarekat Sattariyah. Sampai saat ini kebesaran nama syekh dari ulakan ini sebagai sufi besar tetap

5 Oman Fathurrahman, Urban Sufism; Perubahan dan Kesinambungan Ajaran Tasawuf, http://naskahkuno.blogspot.com/2007/01 urban-sufism-perubahan.html. akses 5 Juni 2018

${ }^{6}$ Ahmad Zahro, Lajnah Bahtsul Masail 1926-1999, Tradisi Intelektual NU, Yogyakarta; LKS, 2004, hal. 24

7 A. Rifai Siregar, Taswuf dari Sufisme Klasik ke Neo Sufisme, Jakarta; PT Raja Grafindo Persada, 1999, hal. 302 
FITRAH Jurnal Kajian Ilmu-ilmu Keislaman

Vol. 04 No. 1 Juni 2018

diabadikan masyarakat pesisir Minangkabau melalui upaca "besafa" di ulakan pada setiap bulan Safar. ${ }^{8}$

Selain tarekat Sattariyah, Naqsabandiyah-khalidiyah juga sangat menonjol dikalangan orang-orang Minangkabau di Sumatera Barat. Tarekat Naqsabandiyah ini salah satu yang terkenal dan mendapat apresiasi dari masyarakat di Simpang Empat Pasaman Barat Sumatera Barat. Selain kedua tarekat tersebut, tarekat yang berkembang di Simpang Empat terdapat juga aliran keagamaan yang menamakan diri Haqqul Yakin Tarekat Naqsabandiyah (selanjutnya disebut Haqqul Yaqin). ${ }^{9}$

Dalam lingkungan Haqqul Yaqin, istilah amalan (ajaran) diberi makna sebagai suatu kepatuhan secara ketat kepada peraturan-peraturan penganut (murid) dan mengamalkan dengan sebaik-baiknya, terkhusus yang bersifat ritual, yaitu dengan menjalankan praktek-praktek wirai. Mengamalkan amalan yang bersifat sunnah baik sebelum maupun sesudah shalat wajib dan memperaktekan riyadhah. Dengan demikian dalam Haqqul Yaqin terdapat dua bentuk amalan (ajaran) yaitu, pertama; ajaran yang dipraktekkan menurut caracara yang dilakukan oleh organisasi-organisasi tarekat, kedua; ajaran yang dipraktekkan menurut cara diluar ketentuan organisasi tarekat.

Dilihat dari konteks zikir atau amalannya tidak diperoleh melalui ijazah guru tarekat besar yang sanad (silsilah guru) bersambung kepada Nabi tanpa terputus, melainkan diperoleh melalui laduni oleh guru. Namun demikian dalam menjalankan syariat agama sama seperti tarekat lainya, berlandaskan alQur'an dan sunnah serta qaul ulama. Hal inilah penulis berkeinginan untuk melakukan penelitian dengan judul Pola Pemahaman Keagamaan Masyarakat Simpang Empat Pasaman Barat (Studi Terhadap Aliran Keagamaan Haqqul Yaqin Tarekat Naqsabandiyah).

\section{KAJIAN TEORI DAN PEMBAHASAN}

\section{Haqqul Yaqin Sebuah Usaha Sufistik}

Secara resmi komunitas Haqqul Yaqin didirikan pada Bulan Oktober tahun 2009 oleh Ustad Edi Lubis di Batang Biyu Kenagarian Lingkuang Aua

8 Sri Mulyati, Mengenal dan Memahami Tarekat-tarekat Muktabarah di Indonesia, Jakarta; Kencana, 2006, hal. 74

${ }^{9}$ Perlu penulis pertegas aliran Haqqul Yaqin Tarekat Naqsabandiyah, tidak ada hubungan dengan Tarekat Naqsabandiyah baik dari ajaran maupun silsilah. 
Kecamatan Pasaman Sumatera Barat. ${ }^{10}$ Berdirinya gerakan Haqqul Yaqin merupakan khazanah baru tentang ketarekatan di Indonesia, tarekat lokal khususnya. Tarekat lokal ini pada dasarnya tidak mempunyai sambungan sanad kepada Nabi Muhammad SAW, sehingga tarekat lokal ini sering dianggap sebagai kelompok sempalan, tidak sah. Karena ajarannya didasarkan pada ajaran-ajaran dan amalan guru tertentu yang bercampur dengan sumber kepercayaan leluhur sehingga sulit menarik garis yang tegas antara tarekat dengan semacam itu dengan aliran kebatinan. Contoh tarekat ini, misalnya Wahidiyah di Jawa Timur, Syahadatain di Jawa Tengah. ${ }^{11}$ Tarekat lainnya seperti Haqqul Yaqin di Pasaman Barat.

Bukan merupakan warisan atau pengijazahan guru tarekat di Timur Tengah, melainkan diperoleh sendiri melalui ilham tanpa guru. Karena tarekat ini muncul tanpa seperti lazimnya tarekat besar diamana ajaran dan amalan diperoleh melalui penyerahan (pengijazahan) oleh seorang guru yang mempunyai urutan silsilah atau sanad secara vertikal sampai kepada Sayidina Ali bin Abi Thalib atau Abu Bakar as-Siddiq yang selanjutnya mendapat ilmu tersebut dari Rasulullah SAW. Silsilah ini merupakan hubungan nama-nama yang sangat panjang, yang satu bertali dengan yang lain. Biasanya tertulis dengan rapi dengan bahasa Arab diatas selember kertas yang diserahkan kepada murid tarekat, sesudah ia melakukan latihan dan amalan, dan sesudah menerima petunjuk-petunjuk irsyad dan peringatan-peringatan, talkin, dan sesudah mengikrarkan janji untuk tidak melakukan maksiat-maksiat yang dilarang oleh gurunya, dan menerima ijazah atau hirqah, sebagai tanda boleh meneruskan lagi ajaran tarekat itu kepada orang lain.

Rangkaian antara guru dan murid pada suatu tarekat tidak selamanya saling mengenal dan berasal dari murid langsung dari guru pendahulunya. Dikarenakan beberapa hal, pertama; diantara mereka hidup tidak satu zaman, kedua; hidup di zaman yang sama tetapi tidak pernah bertemu selama hidupnya. Oleh karena itulah mereka dikenal dengan istilah uwaisyi dan zahabiyah. Adapun ilmu yang didapat oleh gurunya tersebut dipercaya diperoleh melalui pertemuan di alam ruhani, yakni pertemuan bukan di

${ }^{10}$ Edi Lubis (Ustad Haqqul Yaqin) wawancara, di Rumah Kediaman Beliau, tanggal 13 Juli

${ }^{11}$ Mahmud Sajuthi, Politik Tarekat qadiriyah wa Naqsabandiyah Jombang, Yogyakarta; Galang Press, 2001, hal. 7 
FITRAH Jurnal Kajian Ilmu-ilmu Keislaman

Vol. 04 No. 1 Juni 2018

alam sebenarnya. ${ }^{12}$ Maka silsilah kedua ini adalah seseorang dapat saja memperoleh ajaran zikir tarekat melalui silsilah yang tidak langsung asalkan dalam mengamalkan ajaran tetap mengindahkan pada : 1) Mengamalkan syariat Islam, 2) Setia kepada ajaran Islam salah satu dari empat mazhab, 3) mengamalkan ibadah dan mu'amalah sesuai yang dicontohkan oleh ulama salihin.

Cara berzikir di antara berbagai tarekat meskipu memiliki tujuan yang sama tetapi dalam perwujudannya sering kali berbeda. Perbedaan zikir inilah sesungguhnya kemudian sering dijadikan indikator utama perbedaan aliran dalam tarekat. Perbedaan ini disebabkan oleh rumusan temuan mengenai formulasi zikir yang disusun oleh masing-masing pendiri tarekat. Sebaliknya, meskipun jika dilihat dari namanya tarekat memiliki yang bermacam-macam aliran yang berbeda, tetapi pada hakekatnya semua tarekat memiliki kesamaan tujuan, yaitu mak'rifah kepada Allah.

Oleh karena itu sebenarnya sulit untuk mengatakan sebuah tarekat tidak sah, menyimpang dan lain sebagainya jika hanya dilihat dari persoalan ijazah atau silsilah. Jika sebuah tarekat lokal memiliki ajaran dasar yang tidak menyimpang dari al-Qur'an maupun sunnah, sekalipun cara berzikir berbeda dengan tarekat besar, maka sesungguhnya ia patut juga memperoleh predikat sah, murni, dan tidak menyimpang. Begitu juga dengan Haqqul Yaqin jika dilihat dari pengamalan syariat Islam, kesetiaan kepada mazhab islam salah satu dari empat mazhab (mazhab syafii) dan pengalaman ibadah dan mua'amalah mengikuti ahli sunnah wal jamaah.

Pengamalan zikir Haqqul Yaqin sebagaimana yang diungkapkan ustad Edi Lubis adalah sebagai berikut : amalan zikir Haqqul Yaqin dilakukan setelah shalat fardu dengan ketentuan-ketentuan yang telah digariskan. Pelaksanaan ritual zikir dan wirid dimaksudkan ada yang dilakukan secara perorangan, ada yang secara berkelompok. Pengamalan perorangan dilakukan sehabis shalat fardu dan dilaksanakan secara terus menerus tidak

12 Zahabiyah adalah menunjukkan hubungan guru-murid sampai kepada Rasulullah SAW secara langsung (tatap muka), sedangkan uwaisyi adalah hubungan silsilah guru-murid diperoleh melalui mimpi (tidak bertatap muka secara langsung). Lihat Ahmad Syafii Mufid, Gerakan Tarekat di Sekitar Muria, (dalam Majalah Dialog no. 44, Th XX, Departemen Agama, 1996, hal. 19-21., Sementara menurut Martin istilah uwaisyi berasal dari Uwais al-Qarani seorang Yaman yang sezaman dengan Rasulullah SAW, yang tidak pernah jumpa dengan Nabi ketika beliau masih hidup tetapi telah diislamkan oleh ruh Rasulullah setelah beliau wafat. Lihat Martin, Tarekat Naqsabandiyah di Indonesia, hal. 49 
boleh terputus, jika sempat putus berarti tidak lagi memenuhi ketentuan sebagai kaum. ${ }^{13}$

Selain zikir shalat fardu ada lagi amalan yang disebut ritual Jumat malam dan Senin malam, yaitu tawajjuh dan riyadhah (latihan) di lapangan. Ritual ini dilaksanakan setelah selesai shalat Isya dan dilakukan secara berkelompok. Amalan lainnya adalah melaksanakan do'a atau membaca wirid-wirid pada waktu setelah melaksanakan shalat fardu. Tujuan do'a atau wirid ini dimaksudkan untuk mati khusnul khatimah sebelum tertutup pintu taubat, penyembuhan, kanuragan, dan lain-lain. ${ }^{14}$

Disamping amalan rutin yang telah mempunyai ketentuan dan tata cara seperti yang digariskan, Haqqul Yaqin juga mengenal kegiatan ajaran yang bersifat pengembangan wawasan keagamaan dan sosial para jamaah. Kesempatan berkumpul para jamaah, baik ketika pada pertemuan rutin zikir maupun lainnya, dimanfaatin oleh ustad untuk menyampaikan wejanganwejangan baik menyangkut keagamaan maupun tentang kehidupan sosial, ekonomi. Situasi seperti inilah yang sering membuka cakrawala para jamaah untuk terlibat dalam mengambil reaksi atau respon terhadap perkembangan sosial yang berkembang di masyarakat. ${ }^{15}$

Sesungguhnya bila diperhatikan secara seksama, Haqqul Yaqin sulit disamakan dengan aliran-aliran tarekat lokal lain yanh lain, terutama dari ketaatan menjalankan syariat Islam dan sikap komunitas masing-masing terhadap dunia sekitar. Berdasarkan pengkategorian Martin, gerakan keagamaan di Indonesia dapat digolongkan pada dua tipe, yakni pertama sebagai aliran-aliran dengan ajaran yang "aneh" dengan menekankan pengobatan dan kesaktian, tidak mempunyai ciri sosial yang menonjol, tidak ada penolakan terhadap norma-norma masyarakat luas. Tipe kedua gerakan "pemurni" yakni gerakan yang ingin mencari inti yang paling asli dari agamanya, dan melawan segala hal (ajaran maupun amalan) yang dianggap tidak asli. Gerakan pemurni sekaligus adalah juga sebagai reform sosial. Namun demikian tipe kedua ini terbagi kepada dua jenis, yaitu gerakan protes yang mempunyai cita-cita politik tertentu, seperti gerakan Usroh dan

\footnotetext{
${ }^{13}$ Edi Lubis, Wawancara, di Rumah Kediaman Beliau, tanggal 13 Juli 2013

${ }^{14}$ Edi Lubis, Wawancara, di Rumah Kediaman Beliau, tanggal 13 Juli 2013

${ }^{15}$ Liman, Wawancara, di Kedai samping rumah Liman, tanggal 15 Juli 2013
} 
FITRAH Jurnal Kajian Ilmu-ilmu Keislaman

Vol. 04 No. 1 Juni 2018

gerakan yang hanya ingin tatanan nilai Islam berkembang, tidak berharap mengubah tatanan atau sistem politik secara langsung.

Dari pengkategorian Martin tersebut, Haqqul Yaqin tampak berbeda pada jenis tipe terakhir yaitu sebuah kelompok gerakan hanya ingin melihat tatanan nilai Islam berkembang, tidak mengharap mengubah suatu tatanan atau sistem. Oleh karena itu, Haqqul Yaqin bukan tipe gerakan yang mencita-citakan dengan ajaran yang aneh-aneh. Gerakan ini adalah sebuah kominitas yang risau akan makin terdesak dan terpinggirkannya nilai dan moral Islam dari kehidupan umat modernisasi dan sekulerisasi. Melalui Haqqul Yaqin mereka ingin mengajak untuk maju tetapi takut akan larangan Tuhan. Haqqul Yaqin ingin melihat tatanan nilai-nilai dan moral Islam berkembang secara ideal di masyarakat. Dalam konteks teori Glock dan Stark gerakan Haqqul Yaqin ini adalah suatu tipe gerakan yang berawal dari kerisauan (deprivasi) melihat nilai dan moral agama yang makin rusak dan terpinggirkan, kemudian berharap dapat memulihkan atau paling tidak dapat mempertahankan nilai-nilai ideal Islam dalam komunitas Haqqul Yaqin.

Landasan amalan gerakan Haqqul Yaqin, sesuai penuturan para pengikut (jamaah) adalah menggunakan sumber-sumber dari al-Qur'an Hadis serta qaul ulama ahli sunnah wal jamaah. Menyangkut soal hukum (ketentuan agama) gerakan ini tidak mengadakan penafsiran sendiri, akan tetapi mengikuti seluruh hukum yang ada dalam mazhab syafi'i. Dalam perkara tauhid mereka menyebut ahlu sunnah wal jamaah yakni faham imam Abu Hasan Asya'ri. ${ }^{16}$

\section{Haqqul Yakin di Tengah Kecendrungan Sufistik di Indonesia}

Mengenal Haqqul Yaqin Tarekat Naqsabandiyah

Tarekat jamaknya thuruq atau tharaiq secara bahasa berarti jalan atau cara. ${ }^{17}$ Dalam bahasa Arab berarti juga kaifiyyah yang bermakna metode atau sistem al-uslub, juga bermakna mazhab, aliran, haluan al-mazhab atau keadaan al-halah dan bermkna tiang tempat berteduh, tongkat, payung. Harun Nasution mengatakan tarekat berasal dari kata tariqah yaitu jalan yang harus ditempuh seseorang calon sufi dalam tujuan berada sedekat mungkin dengan Tuhan. Tarekat kemudian mengandung arti organisasi

\footnotetext{
16 Saprata, Suwirman, wawancara, di rumah Saprata, tanggal 19 Juli 2013

${ }^{17}$ Ibnu Manzur, Lisan al-Arab, Berut; Dar Ihya al-Turats al-Araby, t.th, hal. 155
} 
(tarekat). Tiap tarekat mempunyai syekh, upacara ritual dan bentuk zikir sendiri. ${ }^{18}$

Penggunaan kata tarekat kemudian secara terminologi ditujukan pada suatu organisasi sosial maupun kewajiban-kewajiban yang ditujukan untuk maksud khusus yang menjadi basis ritual dan struktur kelompok. Maka kelompok sufi mencakup spektrum aktivitas yang luas dalam sejarah masyarakat muslim. ${ }^{19}$

Diantara tarekat yang mula-mula muncul dan berkembang luas dalam perjalanan sejarah nusantara adalah Tarekat qadiriyah di Baqdad, tarekat Rifaiyyah di Asia Barat, tarekat Sazali di Maroko, Naqsabandiyah, Bektsah, Badawiyah, dan lain-lain. Disamping tarekat-tarekat yang demikian ada pula tarekat lokal yang didirikan di Indonesia semisal tarekat akmaliyah didirikan oleh kiyai Nurhakim. Ia dikenal sebagai dukun dan tukang jimat. Tarekat Siddiqiyah didirikan oleh Kiyai Mukhtar Mukti di Losari Plodo (Jombang) pada tahun 1958, ia dikenal sebagai dukun yang sakti sehingga banyak pengikutnya dari kalangan penderita penyakit kronis dan bekas pecandu minuman. Tarekat Wahidiyah didirikan oleh kiyai Majid Ma'ruf dari Kedunglo (Kediri) pada tahun 1963. Haqqul Yaqin Tarekat Naqsabandiyah didirikan oleh ustad Edi Lubis tahun 2009 di Batang Biyu Kenagarian Lingkuang Aua Kecamatan Pasaman Barat.

Melihat secara pasti dari segi historis, kapan dan tarekat mana yang mula-mula timbul sebagai suatu lembaga organisasi nampaknya begitu sulit. Namun secara umum dapat dikemukakan bahwa tarekat-tarekat itu baru muncul atas nama masing-masing sekitar abad dua belas Masehi. Karena kesulitan tersebut, Harun Nasution mencoba melihat secara tahapan perkembangannya saja, yaitu :

a) Tahap khanaqah (pusat pertemuan sufi) disini syekh memiliki sejumlah murid yang hidup bersama-sama di bawah peraturan yang tidak ketat. Syekh menjadi Mursyid yang dipatuhi, kontemplasi dan latihan-latihan spritual dilakukan secara invidual dan secara kolektif.

b) Tahap thariqah yaitu pada masa abad 13 Masehi. Pada masa ini sudah terbentuk ajaran-ajaran, peraturan-peraturan dan metode tasawuf. Pada tahap inilah muncul pusat-pusat yang mengajarkan tasawuf dengan

\footnotetext{
${ }^{18}$ Harun Nasution, Islam Ditinjau dari Berbagai Aspek, Jakarta; UI-Press, 1985, hal. 89

${ }^{19}$ John L. Esposito, Ensklopedi Oxford Dunia Islam Modren, Bandung; Mizan, 2001, Hal. 215
} 
FITRAH Jurnal Kajian Ilmu-ilmu Keislaman

Vol. 04 No. 1 Juni 2018

silsilah masing-masing. Oleh karena itu berkembanglah metode-metode baru untuk mencapai kedekatan diri kepada Allah SWT.

c) Tahap Ta'ifah, tahap ini terjadi pada abad 15 Masehi. Disini terjadi transmisi ajaran dan peraturan kepada pengikut. Pada tahap ini pula muncul organisasi-organisasi taswuf yang mempunyai cabang di tempat lain. Pemujaan kepada syekh telah menjadi kebiasaan dan pada tahap ini pulalah tasawuf telah mengambil bentuk kerakyatan. Pada tahap $t a^{\prime}$ ifah tarekat telah mengandung arti lain, yakni sufi melestarikan ajaran-ajaran syekh tertentu dan terdapatlah tarekat-tarekat. ${ }^{20}$

Dalam tasawuf diterangkan bahwa syariat itu hanya peraturan belaka, tarekatlah yang merupakan perbuatan untuk melakukan syariat itu, apabila tarekat dan tasawuf sudah dapat dikuasai, maka lahirlah hakikat yang tidak lain dari pada perbaikan keaadaan atau ahwal dengan tujuan yang terakhir ialah ma'rifat yaitu mengenal dan mencintai Tuhan dengan sebaik-baiknya. ${ }^{21}$

Dilihat dari ajaran ortodoks Islam, ada tarekat yang dipandang sah dan ada pula yang tidak sah. Suatu tarekat dikatakan sah (muktabarah) jika amalan dalam tarekat itu dapat dipertanggungjawabkan secara syariat. Jika amalan tarekat tidak dapat dipertanggung jawabkan, maka tarekat tersebut dianggap tidak memiliki dasar keabsahan. Tarekat dalam bentuk ini disebut tarekat ghairu muktabarah (tidak sah). ${ }^{22}$ Dengan demikian dapat dipahami bahwa yang dimaksud dengan tarekat muktabarah itu adalah tarekat yang sanad (silsilah) nya muttasil (bersambung) sampai kepada Nabi SAW. Jika sanadnya terputus atau ghaitu muttasil, maka tarekat itu juga ghairu muktabarah atau tidak bersambung kepada Nabi SAW.

Dalam konteks silsilah Haqqul Yaqin termasuk kategori ghairu muktabarah dimana silsilah dan sanadnya tidak bersambung sampai kepada Rasulullah SAW tanpa terputus. Haqqul Yaqin seperti lazimnya tarekat lokal dimana ajaran dan amalan tidak diperoleh melalui penyerahan (pengijazahan) oleh seorang guru yang mempunyai urutan silsilah atau sanad secara vertikal sampai kepada Ali bin Abi Thalib atau Abu Bakar as-

${ }^{20}$ M. Hasbi Amiruddin, Tarikat; Sejarah Masuk dan Pengaruhnya di Indonesia, Madaniya, nomor II, 2000, hal. 21-22

${ }^{21}$ Mustafa Zahri, Kunci Memahami Ilmu Tasawuf, Surabaya; PT Bina Ilmu, 1976, hal. 57

${ }^{22}$ Taufik Abdullah et.al, Tarekat; Ensklopedi Tematis Dunia Islam, vol 3, 2002, hal. 317., lihat juga Amin Syukur, Tasawuf Kontekstual; Solusi Problem Manusia Modren, Yogyakarta; Pustaka, 2003, hal. $45-46$ 
Siddiq yang selanjutnya mendapat ilmu tersebut dari Rasulullah SAW. Maka para ulama menyebutkan tarekat lokal ini ghairu muktabarah. Abdurahman Wahid misalnya, menyebutkan tarekat Wahidiyah sebagai tasawuf non tarekat, sebab legitimasi bagi sebagian pendiri gerakan ini yang berbentuk ijazah diperoleh melalui mimpi. ${ }^{23}$

Untuk menghindari penyimpangan sufisme dari garis lurus yang diletakkan para sufi terdahulu, maka NU meletakkan dasar-dasar tasawuf sesuai dengan khittah ahli sunnah waljamaah. Dalam kerangka inilah Jam'iyyah Ahlith Thariqah al-Muktabarah al-Nahdliyyah (Jatman) dibentuk, yaitu untuk memberikan sebuah rambu-rambu kepada masyarakat tentang tarekat yang muktabarah dan ghairu muktabarah (tidak sah/ sempalan. Dari segi organisasi, Jatman secara de facto berdiri pada bulan Rajab1399H/ Juni 1979M, sebelum terbentuk Jatman, bibit organisasi tersebut telah lahir, yaitu Jamiyyah Thariqah al-Muktabarah suatu badan federal yang dibentuk tahun 1957M, sebagai tindak lanjut dari keputusan Muktamar NU 1957 di Magelang. Belakangan dalam Muktamar NU 1979 di Semarang, ditambahkan kata Nahdliyin, untuk menegaskan bahwa badan ini tetap berafilisiasi kepada NU. Dalam anggaran dasar dinyatakan bahwa badan ini bertujuan :

a. Meningkatkan pengamalan syariat Islam dikalangan masyarakat.

b. Mempertebal kesetiaan masyarakat kepada ajaran-ajaran dari salah satu mazhab yang empat.

c. Menganjurkan para anggota agar meningkatkan amalan-amalan ibadah dan mu'amalah, sesuai dengan yang dicontohkan ulama sholihin.

Alasan ulama mendirikan badan federasi ini adalah untuk membimbing organisasi-organisasi tarekat yang dinilai belum mengajarkan amalan-amalan yang sesuai dengan al-Qur'an dan Hadis dan untuk mengawasi organisasi tarekat agar tidak menyalahgunakan pengaruhnya untuk kepentingan yang tidak dibenarkan oleh ajaran-ajaran agama.

Cara berzikir di antara berbagai tarekat meskipu memiliki tujuan yang sama tetapi dalam perwujudannya sering kali berbeda. Perbedaan zikir inilah sesungguhnya kemudian sering dijadikan indikator utama perbedaan aliran dalam tarekat. Perbedaan ini disebabkan oleh rumusan temuan mengenai formulasi zikir yang disusun oleh masing-masing pendiri tarekat. Sebaliknya, meskipun jika dilihat dari namanya tarekat memiliki yang

${ }^{23}$ Abdurrahman Wahid, Muslim Ditengah Pergumulan, Jakarta; Leppenas, 1983, hal. 39 
FITRAH Jurnal Kajian Ilmu-ilmu Keislaman

Vol. 04 No. 1 Juni 2018

bermacam-macam aliran yang berbeda, tetapi pada hakekatnya semua tarekat memiliki kesamaan tujuan, yaitu mak'rifah kepada Allah. Oleh karena itu sebenarnya sulit untuk mengatakan sebuah tarekat tidak sah, menyimpang dan lain sebagainya jika hanya dilihat dari persoalan ijazah atau silsilah. Jika sebuah tarekat lokal memiliki ajaran dasar yang tidak menyimpang dari al-Qur'an maupun sunnah, sekalipun cara berzikir berbeda dengan tarekat besar, maka sesungguhnya patut juga memperoleh predikat muktabarah.

Seperti yang disebutkan sebelumnya yang membedakan tarekat muktabarah dengan tarekat lokal, antara lain adalah mengenai guru dan ajaran tarekat. Dalam tarekat muktabarah, ajaran dan amalan tarekat diperoleh atau diijazahkan melalui guru tarekat tertentu yang silsilahnya bersambung sampai kepada Nabi SAW. Sementara tarekat lokal, ajaran dan amalannya ditentukan oleh pendiri tarekat yang bersangkutan, tidak diperoleh melaui ijazah yang mempunyai silsilah bersambung sampai kepada Nabi Muhhamd SAW. Oleh sebab itu sering dipandang bahwa ajaran tarekat muktabarah lebih murni atau lebih sesuai dengan syariat islam, sementara ajaran-ajaran tarekat lokal sering dianggap bercampur aduk dengan mistik lokal.

Namun tidak seperti halnya tarekat-tarekat lokal lain, sekalipun amalan-amalan zikir sama-sama diperoleh tanpa melalui ijazah guru tarekat, Haqqul Yaqin dalam menjalankan syariat agama sama seperti tarekat muktabarah yakni berlandaskan al-Qur'an dan Sunnah serta qaul ulama, sehingga dari segi ini Haqqul Yaqin tidak berbeda dengan tarekat muktabarah dan kelompok ahli sunnah waljamaah.

Dalam beberapa hal Haqqul Yaqin tampak kemiripan dengan tarekat lokal lain. Misalnya tarekat lokal pada umumnya cenderung pada kesejahteraan ruhani, ketentraman dan atau kekuatan ghaib individu. Oleh karenanya tarekat lokal seperti ini sering dikategorikan sebagai kelompok kebatinan yang cenderung pada aspek pengobatan, kesaktian, dan sering mencampur ajaran Islam dengan mistik-mistik lokal. Dari sisi ini Haqqul Yaqin mempunyai kemiripan dengan tarekat lokal karena sama-sama memiliki aspek pengobatan, kesaktian, namun antara keduanya berbeda karena Haqqul Yaqin tidak mencampur adukkan ajaran dengan magismagis lain diluar Islam. 


\section{Ajaran dan ritual Haqqul Yaqin}

Amalan Haqqul Yaqin

Setiap tarekat memiliki tradisi ritual masing-masing. Yang dimaksud tradisi ritual dalam tarekat adalah pola-pola aktivitas ritual dan upacara yang menyertainya, yang biasa dilakukan dan menjadi kebiasaan dikalangan anggota tarekat. Secara umum amalan Haqqul Yaqin mencakup dua bentuk, zikir bi al-lisan dan zikir bi al-qalb. Zikir dengan lisan berupa pujaan kepada Allah dalam bentuk amalan, do'a wirid yang menjadi pembuka untuk hudhur al-qalb kepada Allah. Bisa berupa pemeliharaan dan cita-cita batin, menjaga etika, kebebasan dari sifat-sifat lupa terhadap Allah dan berpegang teguh kepada Allah. Sedangkan zikir bi al-qalb adalah upaya menghadapkan hati secara utuh kepada Allah. Zikir ini merupakan metode paling luhur untuk mencapai makrifah kepada Allah.

Mengamalkan tarekat sangatlah perlu dibimbing oleh seorang guru, yaitu pemimpin spritual gerakan ini. Guru tidak hanya memberikan wirid tertentu kepada pengikut tarekat, tetapi juga membantu mereka mengamalkan wirid tersebut. Mursyid secara harfiyah berarti orang yang menunjukkan jalan. Kata ini digunakan dalam tarekat untuk menunjukkan bahwa guru harus memimpin anggotanya dalam rangka mendekati Allah dengan menggunakan cara tertentu.

Wirid adalah merupakan do'a-do'a pendek atau formula-formula untuk memuja Tuhan dan/atau memuji Nabi Muhammad SAW, dan membacanya dalam hitungan kali pada jam-jam yang sudah ditentukan dipercayai akan memperoleh keajaiban atau paling tidak secara psikologis mendatangkan manfaat. Dalam hal ini Haqqul Yaqin melaksanakan ritual wirid secara rutin dan terjadwal. Aktivitas dimaksud sebagi berikut:

a. Wirid. wirid ini harus dilakukan secara perorangan, bacaanya tidak boleh dikeraskan dipraktekkan setiap selesai shalat fardu, diyakini apabila diwiridkan secara terus menerus, ikhlas, penuh keyakinan akan mendatangkan berbagai kelebihan-kelebihan, seperti kekuatan batin, terapi terhadap berbagai penyakit, dan lain sebagainya. Adapun kaifiatnya sebagai berikut :
1) Membaca Bismillahirrahmanirrahim
21 kali
2) Membaca syahadatain
3 kali
3) Membaca shalawat atas Nabi
3 kali 
FITRAH Jurnal Kajian Ilmu-ilmu Keislaman

Vol. 04 No. 1 Juni 2018

4) Membaca surah Alfatihah

11 kali

5) Membaca surah al-Ikhlas

11 kali

6) Membaca surah al-Falaq

3 kali

7) Membaca surah an-Naas

3 kali

8) Membaca ayat Kursi

11 kali

9) Membaca Asma al-hikmah

3 kali

Ya Allah ya Hayyu ya Qayyum ya Azhiimu ya Rabbal 'alamin

Qayyumu yarzuqu mayasya'u quwwat 3 kali

Ya Ilahi anta ma'sudy wa ridhoka mathluby3 kali

Wa ufauwidhu 'amry ilallah

3 Kali

Dalam pelaksanaan wirid Haqqul Yaqin, seorang murid harus mengetahui segala sesuatu yang berhubungan dengan wirid, seperti syarat sah dalam membaca wirid, perbuatan yang membatalkan wirid. Adapun syarat sah dalam membaca wirid sebagai berikut :

1) Suci dari hadas dan najis

2) Menutup aurat

3) Dipraktekkan setelah selesai shalat fardu

4) Tidak boleh berbicara kecuali $u d z u r .{ }^{24}$

Adapun perbuatan yang membatalkan wirid sebagai berikut :

1) Bacaannya kurang, lebih, dan terbalik dengan sengaja

2) Sengaja memutus bacaan

3) Mempermainkan bacaan wirid seperti tidak membaca dengan sungguh-sungguh sampai merubah arti

4) Makan dan minum. ${ }^{25}$

b. Latihan

Aktivitasnya dilakukan dimalam hari tepatnya Jumat malam dan Minggu malam setelah selesai shalat Isya secara berjamaah diperkirakan lebih kurang jam 10.00 WIB, yang diperagakan di lapangan terbuka. Tidak ada larangan bagi msyarakat sekitar yang memiliki kesempatan untuk menyaksikan atau hanya sekedar ingin melihat antaraksi tersebut. Aktivitasnya diawali dengan tausiyah atau mendengarkan Juni 2013

${ }^{24}$ Akhir (perwakilan guru di lapangan) wawancara, di lapangan tempat latihan, tanggal 20

${ }^{25}$ Liman dan Nedi (perwakilan guru di lapangan) wawancara, 20 Juni 2013 
pengajian agama lebih kurang 15 menit yang disampaikan oleh salah seorang dari jamaah yang telah ditunjuk oleh wakil guru dilapangan, kemudian ditutup dengan do'a bersama. Selanjutnya kaifiat latihan sebagai berikut :

1) Perwakilan guru dilapangan nenunjuk seseorang berdiri di tengahtengah lapangan (biasanya pengikut yang baru bergabung, dan kalau seandainya tidak ada murid baru) ditunjuk dari salah seorang dari jamaah.

2) Para murid yang hadir disuruh mengambil posisi di pinggir-pinggir (sudut-sudut) lapangan membentuk lingkaran besar.

3) Personal yang telah ditunjuk berdiri di tengah-tengah lapangan melakukan zikir sir dengan mulut terketup dengan mengangkat ujung lidah ke langit-langit sambil menahan napas semampunya.

4) Perwakilan menyeuruh para murid untuk dikeroyok dan mencelakainya. ${ }^{26}$

Tujuan dari latihan tersebut dari wasil wawancara penulis bersama ustad perwakilan dilapangan dan beberapa pengikut Haqqul Yaqin adalah sebagai berikut :

Pertama; untuk mengetahui kemajuan amalan yang telah diberikan oleh guru, yakni amalan yang tidak kontinyu dikerjakan, tidak menegakkan shalat, tidak seorangpun yang akan berani berdiri di tengah-tengah lapangan kalau amalannya terputus-putus.

Kedua; untuk mematikan ego, bak pepatah mengatakan di atas langit masih ada langit. Kelebihan-kelebihan yang dimiliki hanyalah titipan Allah SWT karenanya jangan pernah merasa sombong serta mepergunakan kelebihan-kelebihan yang dimiliki untuk kemaslahatan.

Ketiga; adanya keadaan-keadaan yang tidak dimengerti, seperti perasaan melayang, hawa dingin diwaktu zikir dan lain-lain segera melaporkan kepada Guru. ${ }^{27}$

${ }^{26}$ Guru, wakil menyuruh untuk melakukan apa saja, semisal meninju, memukul, dengan catatan kejahatan yang ingin dilakukan harus betul-betul dari hati, misalnya menganiaya, memperkosa, membunuh, dan lain sebagainya, anehnya sebelum mereka sempat menjamah dan menyentuh sasaran sudah terpalanting kebelakang duluan, wawancara, dengan Edi Lubis, Nedi, dan Liman, serta hasil pengamatan penulis

${ }^{27}$ Suwirman dkk, wawancara, di depan rumah Edi Lubis, tanggal 20 Juni 2013 
FITRAH Jurnal Kajian Ilmu-ilmu Keislaman

Vol. 04 No. 1 Juni 2018

Ikatan guru/mursyid dengan murid menjadi salah satu hubungan yang disakralkan, namun bukan merupakan sebuah fanatisme buta. Hal ini diyakini sebagai sebuah perilaku yang mulia atau yang disebut dengan akhlaqul karimah. Apapun yang diperintahkan oleh guru pembimbing dipandang sebagai suatu bentuk anjuran yang mesti dilaksanakan. Demikian halnya dijadikan sebagai sebuah bentuk pendidikan untuk selalu memberikan perilaku perseptual yang positif di mata masyarakat. Pola hubungan seperti ini bisa dikategorikan sebagai indikator dari fungsi doktrinal tarekat, yang berhubungan dengan fungsi tarekat secara umum yaitu menjaga kesinambungan antara agama dan masyarakat.

\section{Ritual Haqqul Yaqin Tarekat Naqsabandiyah}

Ajaran tarekat yang dilembagakan oleh komunitas pada dasarnya merupakan bagian dari prinsip-prinsip ajaran Islam sejak awal. Ajaran tarekat tak ubahnya merupakan upaya mendidik diri dan keluarga untuk hidup bersih dan sederhana, serta patuh melaksanakan perintah-perintah agama dalam kehidupan sehari-hari. Ibn Khaldu mengungkapkan, sebagaimana dikutif oleh Ali Yafi dalam buku, Syariah, Thariqah, Haqiqah dan $M a^{\prime}$ rifah bahwa dalam pola tasawuf (tarekat) adalah kedisiplinan dalam beribadah, oriensentrasi tujuan hidup menuju Allah SWT (untuk mendapatkan ridho-Nya) dan upaya membebaskan diri dari ketertarikan mutlak kepada kehidupan duniawi, sehingga tidak diperbudak oleh harta, tahta atau kesenangan lainnya. ${ }^{28}$

Dari rumusan tersebut penulis menyimpulkan bahwa tarekattarekat merupakan bentuk kelembagaan yang terorganisasi untuk membina suatu pendidikan moral dan solidaritas sosial. Sasaran akhir dari pembinaan pribadi dalam pola hidup bertarekat adalah hidup hidup bersih, bersahaja, tekun beribadah kepada Allah SWT, membimbing masyarakat ke arah yang diridhai oleh Allah dengan jalan pengamalan syariah dan penghayatan hakikat dalam metode tarekat untuk mencapai ma'rifah.

Dalam rangka mencapai ma'rifah kepada Allah itulah berbagai tarekat menetapkan metode zikir, amalan, dan ketentuan tertentu. Dari

${ }^{28}$ Ali Yafi, Syariah, Thariqah, Haqiqah, dan Ma'rifah, Jakarta; Yayasan Pramadina, 2004, hal. 
segenap penelusuran melalui wawancara dan pengamatan langsung dengan para pengikut Haqqul Yaqin, tidak ditemukan suatu alasan yang kuat dapat dikategorikan Haqqul Yaqin sebagai suatu bentuk aliran menyimpang. Adapun ajaran atau ritual Haqqul Yaqin sebagai berikut :

1. Zikir

Zikir merupakan amalan pokok yang mendasar di dalam pengaamalan tarekat. Yang dimaksud dengan zikir adalah ucapan yang dilakukan dengan lidah atau mengingat akan Tuhan dengan hati, yaitu dengan ucapan atau ingatan yang mempersucikan Tuhan dan membersihkan-Nya dari sifat-sifat yang tidak layak untuk-Nya serta memuji dengan pujian dan sanjungan dengan sifat-sifat yang sempurna, dan sifat-sifat yang menunjukkan kebesaran dan kemurniaan. ${ }^{29}$

Zikir tersebut dirasakan menjalar ke seluruh anggota tubuh, sehingga benar-benar meresap ke dalam diri. Akhirnya tumbuh rasa cinta melaksanakan semua perintah dan anjuran Allah SWT dan sebaliknya merasa terancam oleh Allah bila hendak mengerjakan kemaksiatan dan yang dibenci-Nya. Dalam kondisi semacam ini seseorang merasakan benar-benar diperhatikan oleh Allah SWT. Pada saat ini terjadi hubungan baik insan dari satu sisi dan Allah dari sisi lain. Sikap insan seperti ini tidak mudah dilakukan, kecuali dengan terus menerus melakukan kegiatan zikir tersebut.

Dalam hal mengamalkan zikir perlu diketahui beberapa aspek penting antara lain, menurut Haqqul Yaqin zikir dapat dilakukan dengan melalui kaifiat sebagai berikut:

a) Seseorang yang hendak melaksanakan zikir harus suci (berwudu' terlebih dahulu) dan duduk di atas sajada.

b) Duduk bersila menghadap kiblat

c) Membaca astagfirullah Allah al-'adzhim sebanyak 5 kali

d) Membaca al-Fatihah sebanyak 1 kali serta ingat maknanya

e) Membaca surah al-Ikhlas sebanyak 1 kali serta ingat maknanya

Setelah ketentuan-ketentuan di atas dilakukan, mulailah berzikir sesuai dengan jumlah yang telah ditentukan oleh

${ }^{29}$ Abu bakar Aceh, Pengantar Ilmu Tarekat; Kajian Historis tentang Mistik, Solo; Ramadhani, 1993, hal.276 
FITRAH Jurnal Kajian Ilmu-ilmu Keislaman

Vol. 04 No. 1 Juni 2018

guru/mursyid. Bila ia selesai melakukan berzikir haruslah membaca do'a sebagai berikut : Ya Allah engkau yang kumaksud dan keridhaan-Mu yang kucari, ya Allah aku mohon taubat dan tetapkanlah aku pada syariat yang mulia.

Dalam ajaran Haqqul Yaqin terdapat empat macam zikir, yang dimaksud sebagai berikut :

Pertama; zikir ismu al-zat yaitu zikir yang dilakukan dengan menyebut lafaz Allah, Allah sebanyak 5000 kali sehari semalam. Boleh dilakukan dengan sekali duduk, kalau tidak mampu dilakukan 1000 kali setiap selesai shalat fardu.

Kedua; zikir nafi itsbat yaitu zikir yang dilakukan dengan menyebut lafaz La Ilaha Ila Allah. Zikir ini dilakukan dengan menahan napas ketika melapalkannya sebanyak 21 kali minimal 3 kali dengan hitungan ganjil. Bila ingin mengakhiri harus membaca Muhammadarrasulullah. Kaifiatnya lafaz la ditarik dari pusat ke kepala, lafaz ilaha ditarik dari kepala diteruskan ke bahu kanan, lafaz illa dari bahu kanan ke lubuk hati, lafaz Allah dimasukkan ke dalam lubuk hati.

Ketiga; zikir tahlil, yaitu zikir yang dilakukan dengan menyebut lafaz la ilaha illa Allah sebanyak 5000 kali sehari semalam. Boleh dilakukan dengan sekali duduk, kalau tidak mampu dilakukan 1000 kali setiap selesai shalat fardu. Kaifiatnya ketika lidah membaca la ilaha illa allah hati mengingat maknanya. Bila jumlah telah tercapai harus membaca muhammadarrasulullah.

Keempat; zikir latifah, yaitu zikir yang dilakukan dengan menyebut Allah, Allah pada tujuh titik halus manusia, yaitu pertama latifah la-Qalb (letaknya dalam hati sanubari) sebanyak 5000 kali dalam sekali duduk, kedua latifahal-Ruh (dua jari dibawah susu kanan) sebanyak 1000 kali sekali duduk, ketiga latifah al-Sir (dua jari diatas susu kiri) sejumlah 1000 kali dalam sekali duduk, keempat latifah al-Khafi (dua jari diatas susu kanan) sejumlah 1000 kali dalam sekali duduk, kelima latifah Ikhfa (di tengah-tengah dada) sejumlah 1000 kali sekali duduk, keenam latifah al-Nafsi (di dahi) sejumlah 1000 kali sekali duduk, ketujuh latifah kullu jasad (dalam tubuh jasmani) sejumlah 1000 kali dalam sekali duduk. 
2. Bai'at

Proses masuknya seseorang menjadi pengikut Haqqul Yaqin melalui sebuah proses yang dinamakan sebagai bai'at. Baiat artinya janji atau sumpah yaitu sumpah pengikut/murid kepada guru untuk melaksanakan segala sesuatu yang telah diikrarkan. Konsekuwensi dari pengikut yang telah dibaiat adalah melaksnakan segala amalan zikir dan wirid, artinya jika tidak dilaksnakan dianggap sebagai suatu pelanggaran dan mendaptkan dosa dari Allah. ${ }^{30}$

Dalam tradisi Haqqul Yaqin ada beberapa sumpah atau janji yang harus diikrarkan disamping sumpah setia para pengikut kepada guru untuk mengamalkan semua amalan yang telah diajarkan oleh guru, yang dimaksud adalah :

1) Tidak akan pernah melakukan perjudian

2) Tidak akan pernah melakukan mabuk-mabukan

3) Tidak akan pernah melakukan perzinahan

4) Tidak akan pernah durhaka kepada kedua orang tua

5) Tidak akan pernah menipu

Apabila melanggar salah satu dari sumpah yang diikrarkan, maka cepat atau lamban akan menerima balasan berupa :

1) Patah sebagian anggota tubuhnya

2) Lumpuh setengah atau seluruh tubuhnya

3) Hancur seluruh tubuhnya. ${ }^{31}$

Sebelum pembaiatan dilakukan diharuskan terlebih dahulu calon pengikut diberi keterangan, bila calon sungguh-sungguh untuk menjadi pengikut, guru akan mengajarkan amalan. Dalam waktu rentang 3 hari/ 5 hari/ bahkan ada yang sampai 7 hari. Guru memanggil calon pengikut untuk menguji kesungguhan dalam pengamalan amalan yang diberikan, aktivitasnya sebagai berikut :

1) Guru menyuruh calon pengikut untuk meminta maaf kepada kedua orang tua bila ia seorang anak, suami kepada istri atau sebaliknya.

\footnotetext{
${ }^{30}$ Warti, Wawancara, di kediaman beliau, tanggal 22 Juni 2013

${ }^{31}$ Edi Lubis, Wawancara, dirumah kediaman beliau, tanggal 22 Juni 2013
} 
FITRAH Jurnal Kajian Ilmu-ilmu Keislaman

Vol. 04 No. 1 Juni 2018

2) Guru menyuruh calon pengikut tidur di atas papan yang ditancapin paku-paku dan meletakkan batako atau batu bata di atas perut calon pengikut yang sebelumnya telah disiapkan.

3) Guru mengisyaratkan calon pengikut melakukan zikir dengan tahan napas.

4) Guru menghujamkan pukulan ke bata yang berada di atas perut seraya mengucapkan lafaz Allahu akbar

5) Selanjutnya guru menyuruh kembali calon pengikut tidur tiatas papan yang ditancapin paku-paku dan meletakkan papan titian diatas perut

6) Kemudian calon pengikut kembali di isyaratkan untuk berzikir dengan nahan nafas

7) Kemudian calan pengikut dilindas dengan sepeda motor

8) Kemudian calon pengikut disuruh mandi taubah dilanjutkan dengan shalat sunnah taubah 2 rakaat.

Setelah selesai segala hal yang tersebut di atas, barulah dilaksanakan baiat oleh guru atau perwakilan guru di bawah alQur'an dan resmilah ia menjadi pengikut Haqqul Yaqin.

3. Tawajjuh

Tawajjuh berasal dari bahasa Arab akar katanya adalah tawajjaha artinya berhadap-hadapan. Yang dimaksud dengan tawajjuh adalah do'a mursyid atau guru kepada Allah SWT, semoga Allah melimpahkan karunia-Nya kepada murid-murid sehingga pengikut orang yang benar-benar dekat dengan Allah. Diharapkan dengan perantaraan tawajjuh pengikut benar-benar merasakan bahagia mendaptkan hidayah Allah SWT sehingga merasakan benar-benar dekat, pikirannya konsentrasi dan ia tidak merasakan segala sesautu di alam ini termasuk dirinya sendiri. Dalam hal ini yang dirasakan berbuat dan berkuasa hanyalah Allah SWT. Perasaan seperti ini tidak dapat diajarkan oleh guru atau mursyid, itu hanyalah semata-mata pemberian Allah SWT.

Dalam Haqqul Yaqin tawajjuh dilaksanakan 2 kali dalam seminggu, yaitu pada jumat malam dan minggu malam, biasanya tawajjuh ini dilakukan sepulang dari aktivitas latihan dari lapangan. Tatacaranya sebagai berikut : 
a) Guru dan murid duduk bersamaan dengan penuh tawadu' membentuk lingkaran cincin.

b) Guru mempersilahkan kepada seluruh yang menghadiri tawajuh untuk menceritakan keadaan-keadaan yang tidak terpahami baik waktu pengamalan wirid, maupun ketiga di lapangan.

c) Guru memberikan wejangan-wejangan dan penjelasan secara umum terhadap kondisi yang dialami oleh pengikut/ murid. ${ }^{32}$

4. Pengobatan

Seperti penulis paparkan sebelumnya, bahwa pengamalan akan amalan dan wirid-wirid secara terus menerus dipercayai akan mendatangkan beberapa kelebihan-kelebihan, di antaranya terapi atau pengobatan terhadap berbagai penyakit. Dari hasil wawancara penulis terhadap guru Haqqul Yaqin serta kepada para komunitasnya, diketahui bahwa seluruh pengikut Haqqul Yaqin memiliki kelebihan-kelebihan yang berbeda-beda antara satu sama lainnya. Kelebihan-kelebihan ini akan dapat mendatangkan manfaat dan mujarab bila yang bersangkutan selalu mengamalkan ajaran dan wirid yang telah diberikan oleh guru.

Dapat diperkirakan bahwa seluruh pengikut Haqqul Yaqin memiliki kemampuan untuk menterapi berbagai penyakit. Dalam praktek pengobatan jamaah Haqqul Yaqin melakukannya dengan ikhlas, maksudnya bila mengobati penyakit seseorang tidak pernah mengharapkan imbalan atau upah, toh kalau diberikan juga mahar dari orang yang diterapi, maka lima persen dari upah/mahar tersebut harus disedekahkan kepada anak-anak yatim guna mengambil berkah serta saran dari guru Haqqul Yaqin. Demikian pula jika seseorang sakit yang sudah bertahun, jika sembuh dari penyakit yang dideritanya hal yang pertama sekali yang mesti dilakukan adalah sukuran dengan menjamu anak-anak yatim.

${ }^{32}$ Wawancara penulis dengan Edi Lubis serta pengamatan penulis secara langsung 
FITRAH Jurnal Kajian Ilmu-ilmu Keislaman

Vol. 04 No. 1 Juni 2018

\section{DAFTAR PUSTAKA}

\section{Sumber Buku}

Abdul Aziz Dahlan, Tasawuf Sunni dan Tasawuf Falsafi; Tinjauan Filosofis, dalam Jurnal Ulumul Qur'an No. 8 Vol. II/1999

Abdurrahman Wahid, Muslim Ditengah Pergumulan, Jakarta; Leppenas, 1983

Abu bakar Aceh, Pengantar Ilmu Tarekat; Kajian Historis tentang Mistik, Solo; Ramadhani, 1993

Ahmad Hasan, Pintu Ijtihat Belum Tertutup, Bandung; Pustaka, 1984

Ahmad Syafii Mufid, Gerakan Tarekat di Sekitar Muria, (dalam Majalah Dialog no. 44, Th XX, Departemen Agama, 1996

Amin Syukur, Tasawuf Kontekstual; Solusi Problem Manusia Modren, Yogyakarta; Pustaka, 2003

Ahmad Zahro, Lajnah Bahtsul Masail 1926-1999, Tradisi Intelektual NU, Yogyakarta; LKS, 2004

Ali Yafi, Syariah, Thariqah, Haqiqah, dan Ma'rifah, Jakarta; Yayasan Pramadina, 2004

A. Rifai Siregar, Taswuf dari Sufisme Klasik ke Neo Sufisme, Jakarta; PT Raja Grafindo Persada, 1999

Harun Nasution, Islam Ditinjau dari Berbagai Aspek, Jakarta; UI-Press, 1985

Ibnu Manzur, Lisan al-Arab, Berut; Dar Thya al-Turats al-Araby, t.th

John L. Esposito, Ensklopedi Oxford Dunia Islam Modren, Bandung; Mizan, 2001

Mahmud Sajuthi, Politik Tarekat qadiriyah wa Naqsabandiyah Jombang, Yogyakarta; Galang Press, 2001

Mustafa Zahri, Kunci Memahami Ilmu Tasawuf, Surabaya; PT Bina Ilmu, 1976

M. Hasbi Amiruddin, Tarikat; Sejarah Masuk dan Pengaruhnya di Indonesia, Madaniya, nomor II, 2000

Martin, Tarekat Naqsabandiyah di Indonesia

Nurcholish Majid, Islam; Doktrin dan Peradaban, Jakarta; Paramadina, 1987 
Oman Fathurrahman, Urban Sufism; Perubahan dan Kesinambungan Ajaran Tasawuf, http://naskahkuno.blogspot.com/2007/01 urban-sufism-perubahan

Simuh, Islam dan Pergumulan Budaya Jawa, Bandung; Teraju, 2003

Sri Mulyati, Mengenal dan Memahami Tarekat-tarekat Muktabarah di Indonesia, Jakarta; Kencana, 2006

Taufik Abdullah et.al, Tarekat; Ensklopedi Tematis Dunia Islam, vol 3, 2002

Yunasril Ali, Esoterisme; Perekat Pluralisme Bangsa, Jakarta, 2005

\section{Sumber Wawancara}

Akhir, wawancara, di lapangan tempat latihan, tanggal 20 Juni 2013

Edi Lubis, Wawancara, di Rumah Kediaman Beliau, tanggal 13 Juli 2013

Liman, Wawancara, di Kedai samping rumah Liman, tanggal 15 Juli 2013

Nedi, Wawancara, 20 Juni 2013

Saprata, Suwirman, wawancara, di rumah Saprata, tanggal 19 Juli 2013

Suwirman dkk, wawancara, di depan rumah Edi Lubis, tanggal 20 Juni 2013

Warti, Wawancara, di kediaman beliau, tanggal 22 Juni 2013 
FITRAH Jurnal Kajian Ilmu-ilmu Keislaman

Vol. 04 No. 1 Juni 2018

\section{Internalisasi Nilai-Nilai Tasawuf Dalam Shalawat Wahidiyah Bagi Pembentukan Karakter Mulia \\ (Studi Kasus di SMK Ihsanniat Rejoagung Ngoro Jombang)}

Rofiatul Hosna

UNHASY Tebuireng Jombang 